\title{
Perilaku Konsumsi Masyarakat Urban Pada Produk Kopi Ala Starbucks
}

\author{
Nadya Afdholy \\ Universitas Negeri Surabaya \\ nadyaafdholy@yahoo.com
}

\begin{abstract}
Abstrak
Kopi Starbucks merupakan produk kopi yang menandakan nilai prestise yang tinggi bagi para penikmatnya karena harganya yang tergolong mahal. Bagi konsumen yang berpendapatan tinggi, tentu bukan hal yang sulit untuk mengonsumsi kopi Starbucks, namun bagi yang berpendapatan rendah mungkin akan berpikir ulang untuk mengonsumsi produk tersebut. Munculnya brand kopi ala Starbucks menunjukkan bahwa saat ini banyak animo masyarakat yang menginginkan kopi tetapi mereka juga melihat keadaan ekonomi mereka yang seutuhnya. Penelitian ini bertujuan untuk mengetahui pola pembentukan identitas yang dimunculkan oleh para konsumen pada produk imitasi ala Starbucks dengan memanfaatkan teori simulakrum dari Jean Baudrillard. Penelitian ini merupakan penelitian deskriptif kualitatif. Penelitian dilakukan di Kafe Starmug's, Kelurahan Keputih, Kecamatan Sukolilo, Kota Surabaya. Sumber data penelitian yaitu hasil wawancara dengan berbagai informan yang merupakan beberapa orang pekerja dan juga mahasiswa di Surabaya yang disebut masyarakat urban. Penelitian ini menggunakan teknik pengumpulan data dengan observasi, wawancara, dan interpretasi. Analisis data dilakukan dengan mendeskripsikan dan memaknai data yang telah diperoleh. Hasil dari penelitian ini menunjukkan bahwa praktik konsumsi kopi ala Starbucks merupakan bentukan konsumerisme postmodern, yakni pola konsumsi yang tidak sesuai dengan arti harfiah dari konsumsi, namun lebih mengarah pada konsumsi simbol-simbol. Kata kunci: imitasi, konsumsi, kopi, posmodernisme, Starbucks.
\end{abstract}

Kata kunci: kopi; konsumsi; starbucks; urban

\begin{abstract}
Starbucks coffee is a coffee product that signifies high prestige for the customers due to the price that is quite expensive. For high-income consumers, it is certainly not a difficult to buy Starbucks coffee, but for those who are not have the highincome they might think to buy the product. The emergence of Starbucks-style coffee brands shows that there are now a lot of public interest in asking for coffee but they also see their full economic situation. The pattern of this study is to identify the raised formation by consumers in Starbucks-style imitation products using the theory of simulacrum by Jean Baudrillard. This study use qualitative descriptive. This study was conducted at the Starmug's Coffee, Keputih Village, Sukolilo District, Surabaya City. The source of data is the result of interviews with various informants representing several workers and also students in Surabaya called urban society. This study uses data collection techniques with observation, interviews, and interpretations. Data analysis is done by describing and interpreting the data
\end{abstract}


that has been obtained. The results of this study showed that Starbucks-style coffee consumption is a form of postmodern consumerism, namely consumption patterns that are not in accordance with the meaning of consumption from consumption, but rather on consumption of symbols. Keywords: imitation, consumption, coffee, postmodernism, Starbucks.

Keywords: coffee; consumption; starbucks; urban

\section{PENDAHULUAN}

Kopi memang telah menjadi bagian erat dalam kehidupan masyarakat Indonesia, terutama lima tahun belakangan ini, dengan masuknya salah satu kedai kopi asing seperti Starbucks ke Indonesia ternyata membawa pengaruh besar terhadap gaya hidup masyarakat urban. Untuk menjadi objek konsumsi, suatu barang harus diubah menjadi tanda (Baudrillard, 2000: 200). Kopi juga tidak bisa dipisahkan dari kehidupan konsumen sehari-hari. Dapur orang-orang di Indonesia adalah sebuah ruang di mana kopi seakan-akan 'harus' ada. Tidak komplet rasanya jika kopi absen dari dapur orang Indonesia. Apalagi akhir-akhir ini berbagai kedai kopi bermunculan di berbagai tempat yang membuat mengonsumsi kopi menjadi sebuah gaya hidup tersendiri. Tak dapat dipungkiri bahwa kehadiran gerai kopi asing juga membuat nama kopi lokal dan budaya minum kopi pun menjadi naik daun. Kehadiran kedai kopi adalah bagian tak terpisahkan dari gaya hidup masyarakat urban. Masyarakat urban lebih memilih kedai kopi untuk nongkrong sambil berdiskusi dan minum kopi. Selain itu, terdapat beragam fasilitas yang didapatkan seperti wifi gratis.

Budaya minum kopi saat ini bukan lagi sebagai aktivitas primordial, yaitu aktivitas biologis dalam memindahkan minuman ke dalam tubuh, tetapi terdapat nilai-nilai sosial yang prestise dalam kegiatan minum kopi. Hal ini terbukti dengan menjamurnya kafe-kafe yang dikemas eksklusif khusus untuk menikmati minuman favorit mereka. Dalam hal ini, kopi telah menjadi minuman favorit penduduk dunia, dan telah dilirik oleh pengusaha untuk dikembangkan menjadi sebuah komoditas untuk diambil keuntungannya. Kopi Starbucks berhasil menjadi ikon kopi dunia yang mampu menjamah pecinta kopi hampir di seluruh dunia.

Kopi Starbucks tentunya sudah tidak asing lagi di telinga masyarakat urban. Produk dari Amerika yang saat ini sudah menjamur di Indonesia ini sudah banyak penikmatnya. Seiring dengan berkembangnya budaya konsumen yang dimiliki oleh masyarakat urban perkotaan, salah satu alternatif adalah memilih hidup yang nyaman dan memiliki prstise tinggi untuk tetap menjaga dan membawa identitas mereka. Kopi Starbucks memang suatu produk kopi yang menandakan nilai prestise yang tinggi bagi para penikmatnya dibandingkan dengan kopi-kopi yang lainnya, karena harga kopi Starbucks tergolong sangat mahal harganya. Namun tidak semua masyarakat urban dapat mengosumsi produk kopi mewah Starbucks. 
Dalam mengonsumsi kopi Starbucks tentunya bagi orang-orang yang mempunyai nilai ekonomi yang tinggi tidaklah sulit untuk menjangkau harga pergelas setiap produk Starbucks, namun bagi konsumen produk Starbucks yang pendapatan rendah mungkin akan berpikir ulang sebelum mereka mengonsumsi produk Starbuks. Minum kopi dikenal lebih dari sekadar aktivitas ketika Starbucks berhasil memberi tambahan 'identitas' kepada para konsumennya. Beberapa saat kemudian, muncul beberapa kedai yang juga terpengaruh oleh Starbucks. Hal tersebut mengikat konsumen yang telah tersegmentasi, atau berkehendak untuk membentuk segmennya sendiri.

Marx mengatakan bahwa ada dua aspek dalam komoditas, yaitu: use value dan exchange value. Nilai guna merupakan kegunaan suatu objek dalam pemenuhan kebutuhan tertentu, sedangkan exchange value menekankan pada nilai tukar yang terkait dengan nilai produk itu di pasar, atau objek yang bersangkutan (Lechte, 2001: 352) Tetapi, apa yang dinyatakan oleh Marx berbeda dengan Baudrillard. Sebuah objek tidak hanya memiliki use value dan exchange value, tetapi juga memiliki symbolic value dan sign value (Pawanti, 2013: 2). Maksud dari pernyataan tersebut bahwa orang tidak lagi mengonsumsi sebuah objek berdasarkan kegunaan dan nilai tukarnya, tetapi juga adanya nilai simbolik dan nilai tanda yang bersifat abstrak.

Berdasarkan latar belakang tersebut, maka rumusan masalah dalam penelitian ini adalah bagaimana pola pembentukan identitas yang dimunculkan oleh para konsumen dalam mengonsumsi produk ala starbuks. Adapun tujuan penelitian ini adalah untuk mengetahui pola pembentukan identitas yang dimunculkan oleh para konsumen dalam mengonsumsi produk ala Starbucks dengan memanfaatkan teori simulakrum dari Jean Baudrillard.

Dalam kapitalisme global kegiatan produksi sudah bergeser dari penciptaan barang konsumsi, ke penciptaan tanda. Baudrilland melihat bahwa konsumen lebih menyukai permainan tanda (status, prestise dan simbol) ketimbang nilai guna, artinya dalam era postmodern tanda dianggap telah mati, yang hadir adalah relasi penanda yang disebut Baudrilland dengan istilah simulakra (Baudrillard, 1998: 60). Baudrilland sepakat dengan konsep milik Barthes, keberkaitan tanda-tanda di masyarakat kapitalisme ada di tahap penandaan yang bagi Barthes disebut dengan istilah konotasi.

Barthes dan Baudrilland berasumsi bahwa kini yang sedang berlangsung dalam proses konsumsi adalah manipulasi tanda. Kode membuat simulasi menjadi penting, karena kode memungkinkan kita untuk menghilangkan realitas, dan hal ini dapat terlihat pada simulasi dan simulakra (Lechte, 2001: 356). Simulasi merupakan dunia yang terbentuk dari hubungan berbagai tanda dan kode, tanpa ada referensi yang jelas. "Simulasi tidak lagi sebagai suatu wilayah, makhluk referensial, atau substansi. Ini adalah generasi oleh model-model nyata tanpa asal atau kenyataan: hyperreal" (Baudrillard, 1994: 1). Simulakra tidak memiliki acuan, yang merupakan duplikasi dari duplikasi, sehingga perbedaan antara duplikasi dan yang asli menjadi kabur.

Simulakra merupakan sebuah istilah untuk menunjukkan sebuah tanda, simbol, dan citra yang ditampakkan bukan saja tidak 
memiliki referensi dalam realitas, justru tanda, simbol dan citra yang dibentuk dan dianggap sebagai representasi dari tanda, simbol dan tanda yang juga merupakan hasil dari simulasi. Citraan dalam simulakra yang tidak memiliki referensi secara bertahap menjadi simulakrum. Simulakrum merupakan proses perubahan citra yang tidak ada kaitannya sama sekali dengan realitas (Pawanti, 2013: 7).

Hiperealitas menciptakan fungsi distinction, yang menurut Baudrillard adalah terciptanya jarak sosial akibat kontruksi suatu kelompok sosial. Individu akan merasa dicap sebagai masyarakat modern, kelas sosial menengah ke atas ketika mereka meminum Starbucks dibanding meminum kopi merek lainnya. Tujuan distinction adalah demi mempertahankan prestise/harga untuk mengejar kehormatan (Ritzer dan Goodman, 2008: 529). Berdasarkan pemaparan pada latar belakang tersebut, penelitian ini bertujuan untuk mengetahui pola pembentukan identitas yang dimunculkan oleh para konsumen pada produk imitasi ala Starbucks dengan memanfaatkan teori simulakrum dari Jean Baudrillard.

\section{METODE}

Penelitian ini merupakan kajian budaya tentang praktik konsumsi yang difokuskan dalam ranah budaya pecinta kopi, yaitu masyarakat urban di Surabaya. Penelitian ini menggunakan kajian literatur dan wawancara sebagai sarana pendukung tentang praktik konsumsi kopi ala Starbucks. Batasan usia yang ditetapkan pada narasumber berusia sekitar kurang lebih 25 tahun. Analisa dari empat responden akan diarahkan untuk menemukan identitas mereka dalam mengonsumsi kopi ala Starbucks. Fenomena yang dikaji dalam penelitian ini adalah praktik konsumsi ala Starbucks pada masyarakat urban di Surabaya. Masyarakat urban Surabaya adalah subjek utama pada objek yang sedang dikaji. Informasi yang dikumpulkan dengan berbicara langsung kepada orang-orang dan melihat mereka bertingkah laku dalam konteks natural inilah yang menjadi karakteristik utama penelitian kuantitatif (Creswell, 2016: 261).

Praktik konsumsi kopi ala Starbucks merupakan bentukan konsumerisme postmodern, yakni pola konsumsi yang tidak sesuai dengan arti harfiah dari konsumsi, namun lebih mengarah pada konsumsi simbol-simbol. Konsumerisme digunakan untuk menganalisa bagaimana perilaku konsumsi posmodern khususnya yang terjadi pada masyarakat urban. Lokasi yang dipilih sebagai tempat penelitian adalah Kota Surabaya, kemudian dilakukan di salah satu kopi ala Starbucks yaitu Starmug's Kopi.

Fokus penelitian ini adalah untuk memahami bagaimana fenomena praktik konsumsi kopi ala Starbucks dimaknai oleh masyarakat urban golongan sosial menengah di Surabaya. Makna dan pengaruhnya menjadi titik balik peneliti membuat hipotesis untuk menemukan identitas yang terbentuk dari konsumsi jenis ini. Dengan pendekatan secara deskriptif dan penganalisaan dalam bentuk studi kasus untuk menemukan gambaran bagaimana masyarakat urban mengonsumsi kopi ala Starbucks sebagai salah satu bentuk pola konsumsi mereka.

Bentuk penelitian ini adalah kualitatif. Metode kualitatif dipilih dikarenakan fenomena yang diambil sebagai bahan 
penelitian adalah fenomena yang sedang menjamur. Metode ini digunakan untuk menganalisa kedalaman fenomena, mempelajari perilaku individu yang terlibat dalam fenomena secara lebih intensif. Dalam metode kualitatif yang disebutkan, peneliti menggunakan tiga teknik pengumpulan data yaitu observasi, wawancara, dan interpretasi.

\section{HASIL DAN PEMBAHASAN}

Littlejohn dalam bukunya yang berjudul Theories of Human Communication mengemukakan bahwa sosial budaya tempat kita tinggal akan menentukan apa yang kita kehendaki dan apa yang kita butuhkan yang kemudian akan merembet pada masalah cita rasa, pilihan, dan keinginan (Arsita, 2017: 9091). Douglas dan Isherwood dalam Featherstone juga berpendapat, bahwa dalam masyarakat saat ini barang-barang digunakan untuk membangun hubungan-hubungan sosial (Featherstone, 1992: 14). Tanda-tanda pada objek konsumsi pada kenyataannya mampu menandai relasi-relasi sosial. Objek konsumsi tersebut menentukan status dan simbol sosial tertentu bagi penggunanya. Barang-barang yang bermerek tertentu menunjukkan nilai sosial yang lebih tinggi. Pada barang-barang tersebut terdapat kode-kode nilai eksklusifitas yang kemudian menjadi penanda bagi pemakainya.

\section{Konstruksi Kedai Kopi yang Mendukung Gaya Hidup}

Edkins dalam bukunya yang berjudul Critical Theorists and International Relations mengemukakan bahwa pada era simulasi saat ini, manusia dihadapkan pada makna kehidupan yang seolah-olah semu belaka tatkala tanda tidak lagi mewakili sesuatu apa pun, tetapi justru seolah-olah menciptakan kenyataan baru (Arsita, 2017: 90). Konsumsi yang dilakukan masyarakat urban bukan lagi sekadar kegiatan pemenuhan kebutuhankebutuhan dasar dan fungsional manusia.

Masyarakat hanya mengonsumsi citra yang melekat pada barang tersebut (bukan lagi pada kegunaannya) sehingga masyarakat sebagai konsumen tidak pernah merasa puas dan akan memicu terjadinya konsumsi secara terus menerus, karena kehidupan sehari-hari setiap individu dapat terlihat dari kegiatan konsumsinya, barang dan jasa yang dibeli dan dipakai oleh setiap individu, yang juga didasarkan pada citraan-citraan yang diberikan dari produk tersebut (Murti, 2005: 38). Masyarakat tidak cukup hanya mengonsumsi sandang, pangan, dan papan saja untuk bisa bertahan hidup.

Sebagai suatu budaya, konsumsi mempengaruhi kehidupan sehari-hari dan menstruktur praktik keseharian masyarakat. Nilai-nilai, pemaknaan dan harga dari segala sesuatu yang dikonsumsi menjadi semakin penting dalam pengalaman personal dan kehidupan sosial masyarakat. Konsumsi telah terinternalisasi dalam rasionalitas berpikir masyarakat dan teraplikasikan dalam kehidupan sehari-hari. Masyarakat konsumeris adalah masyarakat yang menciptakan nilai-nilai yang berlimpah ruah melalui barang- barang konsumeris, serta menjadikan konsumsi sebagai pusat aktivitas kehidupan (Piliang, 2003: 17). Setiap harinya, sekian banyak waktu bisa dihabiskan untuk berkonsumsi, berpikir tentang apa yang dikonsumsi dan menyiapkan apa yang akan dikonsumsi sebagai gaya hidup. 
Gaya hidup selanjutnya merupakan caracara terpola dalam menginvestasikan aspekaspek tertentu kehidupan sehari-hari dengan nilai sosial atau simbolik; tetapi ini juga berarti bahwa gaya hidup adalah cara bermain identitas (Chaney, 1996: 92). Oleh karena itu, masyarakat harus bekerja untuk dapat memenuhi kebutuhan konsumsinya, memberi penilaian kepada orang lain berdasarkan apaapa yang dikonsumsinya, menandakan identitas diri dengan benda-benda konsumsi, berhubungan dengan orang lain berdasarkan keterikatan pada benda konsumsi, yang dari kesemuanya itu merupakan cara berpikir untuk pemenuhan gaya hidup konsumerisme.

Dunia memerlukan cara memandang kehidupan dengan kacamata yang berbeda. Dari era modernisme, posmodernisme hadir untuk menentang modernisme itu sendiri, yang bagaikan membunuh rasionalitas manusia (Arsita, 2017: 96). Posmodernisme yang merupakan sebuah aliran pemikiran, lalu berkembang menjadi semacam paradigma baru yang merupakan antitesis dari modernisme yang dinilai telah gagal dan tidak lagi relevan dengan perkembangan zaman. Posmodernisme muncul dengan berbagai instrumennya sebagai dukungan atas kebudayaan massal yang makkin merasuki kehidupan manusia masa kini.

Fenomena membeli kopi di Starbucks erat kaitanya dengan pergeseran konsep status of object milik Baudrillard, yaitu hilangnya nilai fungsi kopi yang sebenarnya. Jika Marx selalu menekankan bahwa kapitalis tugasnya memproduksi barang, sedangkan bagi Baudrilland kapitalis memproduksi tontonan, karena konsumen menginginkan sebuah differensiasi melalui permainan tanda-tanda di dalam produk. Baudrilland menyempurnakan bahwa era kapitalis dapat dilihat dari produksi tontonan, yaitu tontonan apa yang bisa disajikan dari secangkir kopi Starbucks? Tanda-tanda apa yang dicari konsumen dari secangkir kopi tersebut. Starbucks dimaknai dengan wujud materil berupa kopi yang diminum, namun dalam konsep simulakra kopi yang bersifat konkret ini mampu berubah menjadi abstrak (imajinasi) dengan penunjang harga jual yang tinggi sehingga menciptakan imajinasi lain atau biasa yang disebut Baudrillard dengan hiperealitas ketika ketika para konsumen meminum kopi dengan merek Starbucks dibanding kopi dengan merek lainnya.

Baudrilland mengatakan bahwa massa hanya menginginkan tontonan, mereka hanya menginginkan permainan tanda, stereotip dan mengidolakan kandungan isi (Baudrilland, 1983: 10). Dalam konteks tersebut dapat diartikan bahwa kopi tidak lagi dibeli sebagai minuman penghilang kantuk belaka, namun ada nilai-nilai simbolik yang melekat dan harus dibayar mahal untuk mendapatkannya. Selanjutnya, Baudrillard memiliki konsep bernama simulakra. Simulakra yaitu duplikasi yang aslinya tidak pernah ada, sehingga perbedaan antara duplikasi dan yang asli menjadi kabur. Konsumerisme yang selama ini diartikan sebagai tindakan membeli sebuah produk berdasarkan nilai fungsinya menjadi tertindih oleh fungsi-fungsi sosial lain. Berdasarkan hal tersebut, masyarakat konsumeris mulai melirik kedai kopi serupa Starbucks. 
Pola Konsumsi Kopi Ala Starbucks di Surabaya

Surabaya merupakan salah satu kota industri terbesar di Indonesia. Salah satu konsekuensi dari kemajuan kota adalah menjamurnya usaha-usaha di berbagai bidang, termasuk usaha jasa di bidang kuliner yang sedang menjamur. Menjamurnya kedai kopi yang mirip dengan Starbucks dinilai dapat menarik minat konsumen. Ada beberapa tempat kopi yang mempunyai logo, warna, dan nama yang mengingatkan dengan jaringan kopi internasional, Starbucks. Salah satunya adalah warung kopi yang bernama Starmug's yang berada di daerah Surabaya Timur, tepatnya di Kelurahan Keputih, Kecamatan Sukolilo, Kota Surabaya. Berikut adalah contoh logo Starbucks Coffee dengan Starmug`s Coffee.
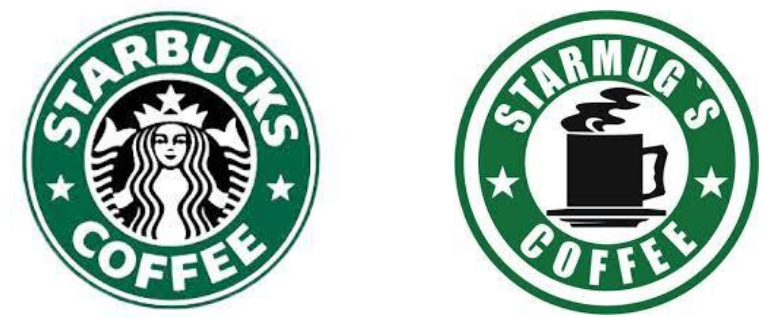

\section{Gambar 1. Perbandingan logo strabucks dan Starmug's}

Kopi Starmug's adalah salah satu kopi yang logonya memiliki kemiripan dengan kopi Starbuks. Jika dibandingkan, perbedaan logo Starbucks dan Starmug's Coffee hanya sedikit. Gambar putri duyung yang terdapat di logo Starbucks diganti dengan gambar cangkir kopi. Dalam beberapa konsumen yang kami wawancarai dalam pengumpulan data ini ada beberapa hal yang menarik dalam upaya pemenuhan identitas mereka dalam mengonsumsi kopi Starbucks. Pemenuhan kebutuhan minum kopi sebagai suatu gaya hidup baru banyak dialami oleh para pekerja yang hidup di perkotaaan. Beberapa sampel yang kami wawancarai merupakan variasi dari beberapa orang pekerja dan juga mahasiswa di Surabaya.

Konsumen pertama yaitu Novitasari (karyawan Jakarta Pos). Novitasari kerap menghabiskan waktu untuk sekadar berkumpul dengan teman-temanya di kopi Starmug's. Hal tersebut dilakukan karena ketika ia mengonsumsi kopi Starbucks, ia merasa bukan kelasnya dan terlalu tingginya nilai harga jual yang ditawarkan Starbuks, sehingga ia tidak mengkosumsi kopi Starbuks dan memilih kopi Starmug's. "Nggak cukup kantongku kalau ngopi di Starbucks, bukan kelasku, mending di sini (Starmug's) samasama ngopi tapi harganya tetap bisa terjangkau dan tidak kelihatan terlalu wah". Mengonsumsi kopi Starmug's dipilih Novitasari sebagai alternatif untuk minum kopi di tempat yang tidak menjadi icon high class. Di samping itu, faktor ekonomi juga mempengaruhi cara Novitasari memilih tempat untuk mengonsumsi kopi.

Konsumen kedua yaitu Fajrin, seorang guru di salah satu sekolah swasta di Surabaya. Fajrin mengonsumsi kopi ala starbuks dikarenakan dia ingin tercitrakan sebagai seseorang yang memiliki gaya hidup elite namun tetap dengan harga yang bersahabat. "Rasanya ngak jauh beda dengan kopi Starbucks, yang penting tetap bisa ngopi di tempat yang nyaman dan harganya juga terjangkau”. Hampir sama juga dengan apa yang disampaikan oleh konsumen-konsumen lain, Fajrin memilih untuk mengonsumsi kopi Starmug's yang mirip dengan Starbucks 
dengan alasan rasa yang tidak jauh berbeda dengan harganya yang cukup terjangkau.

Konsumen ketiga yaitu Febbry, salah satu mahasiswa ITS yang juga pencinta kopi. "Ngopi di Starbucks sama saja rasanya, itu hanya untuk pemenuhan status sosial lagi pula kalau ngopi di Starbucks ribet keluar masuk mall, mending di kopi biasa aja, lebih terjangkau". Menurut Febbry, ngopi di tempat Starbuks tidak lebih adalah untuk pemenuhan status sosial saja, kalau dari segi rasa sama saja dengan kopi-kopi biasa.

Konsumen keempat adalah Fani, seorang mahasiswi dari sebuah universitas di Surabaya. "Ngopi tetap harus jalan, tapi nyari tempatnya harus tetep bersahabat, nggak harus mahal, yang penting nyaman dan kelihatan bermerek tempatnya". Meskipun dia belum berpenghasilan rutin namun dia kerap menjalankan ritual ngopi bersama temantemanya untuk memenuhi gaya hidup.

Mengonsumsi merek terkenal bukan salah satu pilihan bagi orang yang berpendapatan untuk menghabiskan waktunya untuk sekadar minum kopi di tempat yang mahal. Identitas yang dibangun pada kafe Starbucks juga tentunya sudah memberi image kelas tinggi bagi para penikmatnya. Penikmat kopi Starbucks hanya dapat dijangkau oleh orang-orang yang memiliki pendapatan tinggi. Oleh karena itu, dari konsumen pertama yang kami wawancarai, mereka lebih memilih kafe yang serupa dengan Kafe Starbucks utuk membentuk image mereka sebagai orang yang tidak berada di kelas tinggi. Namun mereka tetap bisa merasakan kopi yang tampilannya hampir sama dengan kopi Starbucks.

\section{Perilaku Konsumsi Masyarakat Urban pada Produk Imitasi}

Tatanan masyarakat dewasa ini menurut Jean Baudrillard telah disasari oleh rasionalitas hedonisme yang bertumpu pada pemuasan kebutuhan dan kesenangan melalui konsumsi. Jika kita amati di sekeliling kita, kehidupan tradisional yang penuh dengan ajaran-ajaran kesalehan, kesederhanaan, sifatsifat altruistic dan pengekangan hasrat atau nafsu telah mengalami banyak pergeseran menjadi kehidupan yang bertumpu pada moral hedonik yang mengedepankan pemborosan yang disebarkan oleh media massa (Baudrillard, 1998: 25).

Masyarakat urban yang memiliki banyak variasi dalam jumlah pendapatan tentunya menjadi salah satu faktor dalam menentukan tempat mereka memilih apa yang mereka konsumsi. Upaya mendapatkan sesuatu yang memiliki nilai tinggi tidak selamanya harus mencari yang original lagi bagi masyarakat urban. Banyak tempat-tempat yang mampu menujukan kelas-kelas elit dari tempat-tempat atau produk yang tidak original. Originalitas bagi sebagian masyarakat urban memang sesuatu yang sulit di dapatkan.

Fenomena mengonsumsi produk imitasi yang dilakukan oleh masyarakat urban menunjukkan adanya negosiasi dari identitas sosial satu dengan yang lainnya. Identitas sosial tinggi menjadi suatu hal yang pastinya ingin dimiliki semua orang. Hal tersebut dilakukan dengan cara mengonsumsi barangbarang atau produk yang mahal dan bernilai tinggi. Namun, dari sisi lain terdapat faktor lain yang menjadi hal yang butuh dinegosiasikan untuk tetap mendapatkan 
identitas tersebut meskipun dari tempat yang tidak sama dengan aslinya.

Peminum kopi memiliki pandangan dan penilaian dari rasa minum kopi yang enak, suasana yang nyaman, fasilitas lengkap dan pelayanan yang baik yang ditawarkan oleh setiap kedai kopi (Solikatun, 2018: 72). Dikaitkan nilai guna kopi Starbucks untuk penghilang kantuk dan penambah stamina, nilai tukar yaitu dengan harga kopi Starbucks yang mahal setara dengan bahan-bahan kopi berkualitas, fasilitas seperti wifi dibanding kopi pinggiran dengan harga jauh lebih murah dan fasilitas seadanya, kemudian berlanjut ke nilai simbolik yaitu kopi Starbucks identik dengan gaya hidup modern dan pada tahap akhir pertukaran nilai objek tanda yaitu objek seperti kopi dapat menjadi petanda pembeda sosial antar kelompok masyarakat dan sebagainya.

Setiap individu ingin mendapatkan pengakuan dari lingkungan sosialnya. Banyak cara yang dapat ditempuh untuk mendapatkan pengakuan tersebut, salah satunya adalah dengan memiliki barang-barang yang dianggap berkelas dan mahal. Barang bermerek seringkali dikaitkan dengan status sosial seseorang. Para pemakainya sering dipersepsikan sebagai pribadi kelas atas, elegan, dan terpandang. Merek adalah jaminan tidak langsung sebuah kualitas. Merek yang dibanderol harga tinggi dianggap memiliki kualitas tinggi pula.

Munculnya tempat-tempat yang menjadi tempat untuk minum kopi menjadikan kopi sebagai suatu penanda status atau identitas masyarakat. Saat ini bukan kopi saja yang menjadi penentu identitas sosial masyarakat tetapi tempat juga menjadi penentu. Brand dari merek suatu kafe menjadi salah satu penentu status sosial dan menunjukan identitas masyarakat tersebut. Munculnya kopi-kopi yang serupa dengan brand kopi yang terkenal menyatakan bahwa saat ini bayak sekali animo masyarakat yang menginginkan kopi namun mereka juga harus melihat bagaimana upaya atau keadaan mereka yang seutuhnya.

Membangun citra dan identitas diri tentunya sangat penting bagi kehidupan sosial masyarakat. Apa yang dikonsumsi oleh masyarakat menjadi suatu hal yang dapat mencerminkan diri kita. Begitu juga dalam penelitian ini. Para konsumen kopi ala Starbucks ingin menggeser identitas kelas tinggi dengan meninggalkan kafe Starbucks dan memilih merek yang serupa. Hal tersebut tidak sejalan dengan pendapat Baudrillard yang menyebutkan bahwa konsumen telah disasari oleh rasionalitas hedonisme yang bertumpu pada pemuasan kebutuhan dan kesenangan melalui konsumsi. Jadi, jika diamati di sekeliling kita kehidupan yang tradisional yang penuh dengan ajaran-ajaran kesalehan, kesederhanaan, sifat-sifat altruistic dan pengekangan hasrat atau nafsu telah mengalami banyak pergeseran menjadi kehidupan yang bertumpu pada moral hedonik yang mengedepankan pemborosan yang disebarkan oleh media massa.

Dalam masyarakat konsumsi, masyarakat hidup di suatu bentuk relasi subjeksubjek yang baru, yaitu relasi konsumerisme. Bentuk relasi sosial tersebut menggiring masyarakat urban guna mempelajari dan menginternalisasikan kode-kode sosial dari berbagai objek konsumsi melalui media massa dan lingkungan sosial. Perkembangan budaya konsumsi yang berjalan seiring perkembagan 
media massa menghasilkan dampak yang signifikan dalam kehidupan manusia, terutama yang berkaitan dengan relasi sosial berdasarkan rasionalitas konsumsi. Fenomena mengonsumsi produk imitasi yang dilakukan oleh masyarakat urban menunjukan adanya negosiasi dari identitas sosial yang satu dengan yang lainnya. Identitas sosial yang tinggi menjadi suatu hal yang pastinya ingin dimiliki semua orang, salah satunya dengan cara mengonsumsi barang-barang atau produk mahal dan bernilai prestise yang tinggi. Namun, dari segi lain banyak juga faktor lain yang menjadi hal yang butuh dinegosiasikan untuk tetap mendapatkan identitas tersebut meskipun dari tempat yang tidak sama dengan yang aslinya.

\section{KESIMPULAN}

Berdasarkan penelitian dan pembahasan yang dilakukan terhadap praktik konsumsi masyarakat urban pada produk ala Starbucks, maka dapat disimpulkan bahwa para konsumen tidak hanya mengejar identitas sosial, tetapi ada hal lain yaitu kenyamanan dan ekonomis. Uang menjadi salah satu faktor paling kuat dalam mengonsumsi produk imitasi. Faktor ekonomi menjadi dasar yang kuat saat ini dalam pemenuhan gaya hidup. Bukan lagi identitas diri yang ingin didapatkan namun kenyamanan serta kemiripan produk yang meskipun bukan produk original yang menjadi salah satu keinginan yang ingin dicapai dalam mengonsumsi produk imitasi. Artinya masyarakat urban saat ini bukan hanya mengedepankan identitasnya, tetapi lebih mengutamakan faktor ekonomi dalam setiap tindak konsumsi.

\section{DAFTAR PUSTAKA}

Arsita, A. (2017). Simulakra Baudrillard dalam Multidimensi Posmodernisme: Kajian Fotografi Makanan dalam Media Sosial Instagram. Rekam Vol. 13 No. 2.

Baudrillard, J. (1983). The Precession of Simulacra. New York: Semiotext.

Baudrillard, J. (1994). Simulacra and Simulation. London: University of Michigan Press.

Baudrillard, J. (1998). The Consumer Society; Myth and Structure. London: Sage Publication.

Baudrillard, J. (2000). The Systems of Objects. London: New York Verso.

Chaney, D. (1996). Lifestyle : Sebuah Pengantar Komprehensif. Yogyakarta: Jalasutra.

Creswell, J. W. (2016). Research Design: Pendekatan Kualitatif, Kuantitatif, dan Mixed. California: SAGE Publications.

Edkins, J. (2009). Critical Theorists and International Relations. Abingdon: Routledge.

Featherstone, M. (1992). Consumer Culture and Postmodernism. London: Sage Publication.

Lechte, J. (2001). 50 Filsuf Kontemporer. Yogyakarta: Kanisius.

Littlejohn, S. W. (2008). Theories of Human Communication. Belmont: Thomson Wadsworth.

Murti, A. (2005). Perbandingan Konsep Consumer Society dalam Pemikiran Jean Baudrillard dan Herbert Marcuse. Depok: Universitas Indonesia. 
Pawanti, M. H. (2013). Masyarakat Konsumeris Menurut Konsep Pemikiran Jean Baudrillard. Depok: Universitas Indonesia.

Piliang, Y. A. (2003). Hipersemiotika; Tafsir Cultural Studies Atas Matinya Makna. Yogyakarta: Jalasutra.

Ritzer, G., \& Goodman, D. J. (2008). Teori Sosiologi Modern. Jakarta: Kencana.

Solikatun, Kartono, D. T., \& Demartoto, A. (2018). Perilaku Konsumsi Kopi sebagai Budaya Masyarakat Konsumsi: Studi Fenomenologi pada Peminum Kopi di Kedai Kopi Kota Semarang. Jurnal Analisa Sosiologi, 60-74. 